\title{
DR. DALMY DÉNES ELÖADÁSA A PALOTÁS-DÍJ ÁTADÁSAKOR
}

A fib Magyar Tagozata Palotás László-díjasának írása

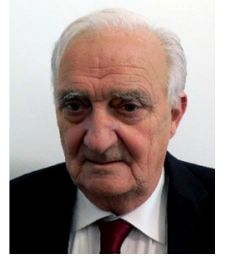

https://doi.org/10.32969/VB.2021.1.2

Dr. Dalmy Dénes

\section{BEVEZETÉS}

Tisztelt Kuratórium, Balázs L.György és Palotás László professzor urak, nagyon köszönöm, hogy az ez évi Palotás László-díjat nekem ítélték. Külön öröm számomra, hogy olyan uraknak köszönhetem meg ezt a munkásságomat elismerő díjat, akiknek édesapjuktól hallottam elöször a vasbetonról és tanultam meg, hogy milyen nagyszerü építőanyag. Palotás László édesapja tanította meg az Egyetemen az akkori idők legkorszerübb vasbeton elméletét, Balázs György professzor úr édesapja a vasbeton hidak gyakorlatait vezette. Olyan lelkesedést oltottak belém, hogy az egész életemben a vasbeton szerkezetekkel foglalkoztam.

Nagyon örülök, hogy Bölcskey Elemér professzor úrral együtt kaphatom meg ezt a díjat, akinek édesapja a Vasbetonszerkezetek Tanszék vezetője, professzora volt, akinek bölcs útmutatásával, irányításával véglegesen eljegyeztem magam a vasbeton és feszített vasbeton szerkezetek tervezésével, építésével.

Közel hatvan éves szakmai életutamat édesapám, Dalmy József vizes mérnök szakmaszeretete és bátyám, Dalmy Tibor iránymutatása indította el, aki példaképem volt és az éppen érettségiző öccsének azt javasolta ,gyere mérnöknek, majd együtt tudunk dolgozni”,Ez csak diplomám után harminc évvel valósulhatott meg.

Közel 60 éves szakmai munkám lényegében két részre osztható:

- a Mủegyetem Vasbetonszerkezetek Tanszékén tanítottam,

- tervezés és kivitelezés, mely a kapitalizmus hajnalán 1990-ben indult.

A két rész persze nem választható el egymástól élesen, hiszen mint egyetemi oktató terveztem, és mint vállalati ügyvezetö tartottam elöadásokat.

Szakmai életem úgy tünik, teljes értékü lett az egyetemi oktatás, a tervezés, kivitelezés együttesével.

Szakmai fejlödésemet nagyban segítették külföldi tanulmányútjaim; Lengyelországban, Dániában, az Irakban töltött kétéves tervezői munkám. 2008-2016 között a Mérnöki Kamara Tartószerkezeti Tagozatának elnökeként az Eurocode 2010-2011 bevezetésére tett tagozati erőfeszítéseként egy év alatt 11 könyv jelent meg, a tervezők támogatására (1. ábra).

Külön kiemelem Robert Ratay amerikai professzor barátomat, aki nagyon sokat segített, hogy nemzetközi kapcsolataim bővüljenek, félévszázados barátságunk és hosszú New York - Budapest beszélgetéseink nyomán a legfrissebb, első kézből származó értesülések révén több szerkezet tönkremenetelének okát ismerhettem meg.

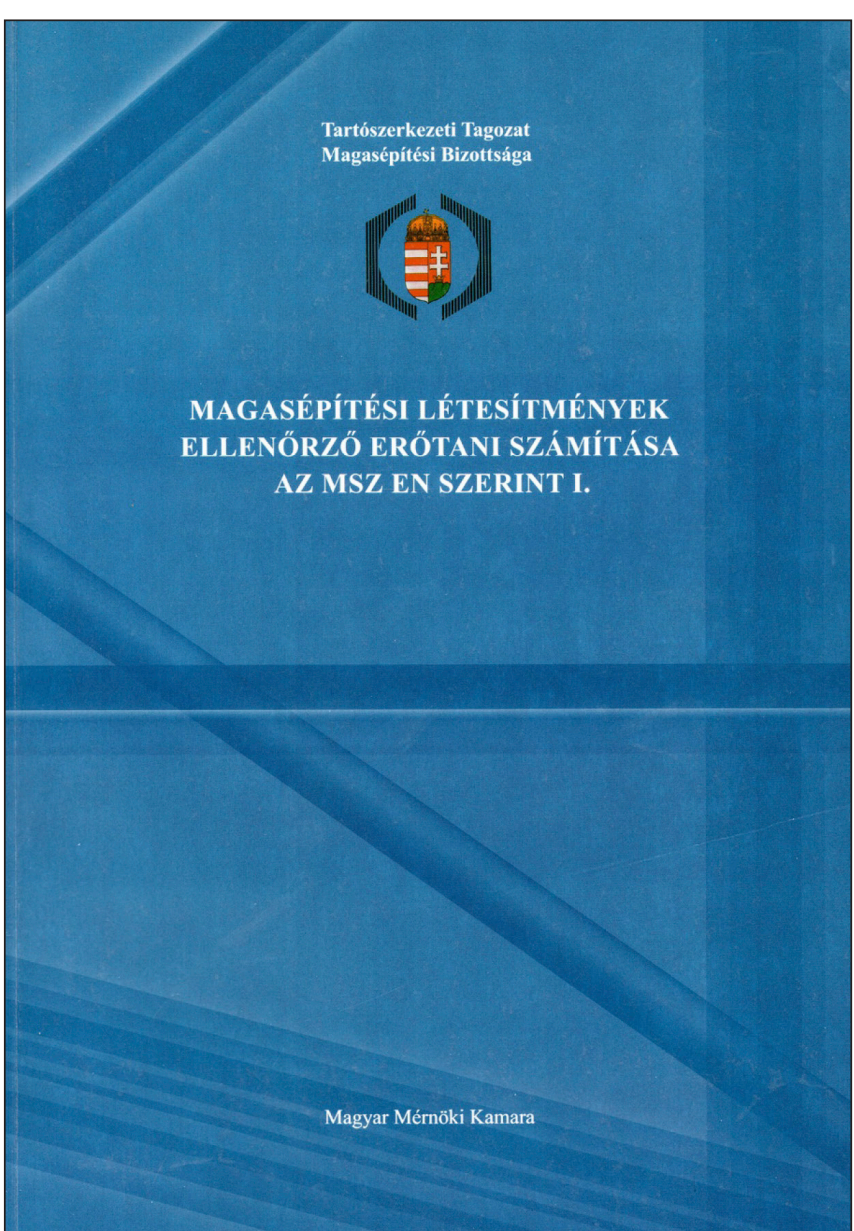

1.ábra: az MMK Tartószerkezeti Tagozata 11 könyvet jelentetett meg az Eurocode bevezetésének megkönnyítésére

\section{TANITTÁS A BME VASBETON- SZERKEZETEK TANSZÉKÉN}

A Múszaki Egyetemen 1962-ben diplomáztam, majd két évet a KÉV-nél (Közlekedési Építő Vállalat) dolgoztam, ahol építésvezető lettem.

1964-ben a BME Vasbetonszerkezetek Tanszékére felvettek tanársegédnek. Klatsmányi Tibor értesített először, hogy a tanársegédi pályázatot elnyertem. A Vasbetonszerkezetek Tanszéken aztán évtizedekig egy szobában ültünk és egy életre szóló barátságot kötöttünk vele, aki a győri Egyetem alapító tagja volt.

A Tanszékvezető Bölcskei Elemér akadémikus, számtalan vasbeton híd tervezője volt. Töle tanultam meg, mit is jelent a szerkezetben gondolkozni, hogyan lehet egyszerü eszközök- 
kel megállapítani, hogy egy szerkezet nem megfelelő, gazdaságtalan, vagy kiváló.

A Tanszék fontos gyüjtőhelye volt a háború előtti és utáni nagy tervező mérnököknek, akiknek szerkezeteit manapság is nagy tisztelettel vizsgáljuk, ők Bölcskei barátai, tervezőtársai voltak.

Így ismertem meg

Mistéth Endrét,

Hilvert Eleket,

Menyhárd Istvánt,

Csonka Pált.

Az volt a szerencsém, hogy Menyhárd István Héjszerkezetek szakmérnöki kurzusára tárgyfelelősnek beosztottak, így a héjszerkezetek mellett sok érdekes tartószerkezeti problémát megismerhettem, Menyhárd István Héjszerkezetek könyvének sajtó alá rendezését is végezhettem.

Menyhárd István igazi szerkezetépítő mérnök volt, aki hidat, az ország legnagyobb fesztávolságú héjszerkezetét egyaránt meg tudta tervezni.

A Vasbeton hidak tárgy gyakorlati óráin kiváló hídtervezőkkel dolgoztam együtt, Loykó Miklóssal, Knebel Jenővel.

Az 1970-es években az FTV-nél statikus ellenőr voltam.

1972-ben készítettem el doktori disszertációmat.

1978 és 1980 között Bagdadban (Irak) egy magasépítési tervezőirodában statikus tervezőként vasbetonszerkezetü épületeket terveztem, többek között 600 ágyas kórházat, 25000 féröhelyes stadiont.

Számtalan mérnöktovábbképző, szakmérnöki előadást tartottam.

\section{TERVEZŐ ÉS KIVITELEZŐ ÉVEIM}

1990-ben alapítottuk meg a Pannon Freyssinet Kft-t, ahol ügyvezető igazgató lettem.

Itt váltottuk valóra, hogy Tibor bátyámmal együtt dolgozhattam több, mint 15 évet.

Hozzánk jött dolgozni Loykó Miklós és Farkas György professzor is, mint tulajdonostárs is besegített a tervezési munkákba.

Az anyacég Freyssinet International \& Cie, szívesen segített beindítani a munkát, azonban a fö tevékenységi körét, az utófeszítést a Hídépítő Vállalat lefoglalta.

Gyorsan felismertük, hogy csakis innovációval tudunk talpon maradni, így aztán behoztuk Magyarországra

- a külsőkábeles feszítési technológiát,

- a talajtámfal eredeti megoldását,

- a végleges talajhorgonyt,

- a Menard-féle talajtömörítést.

Ezeknél a technológiáknál teljeskörü szolgáltatást adtunk, azaz megterveztük, megépítettük a külsőkábeles feszítést.

Azt kell mondanunk, hogy 1990-ben megalkottuk a Design \& Build megoldást, hiszen amit megterveztünk, megépítettük.

A Kft. munkája az ott dolgozó kiváló mérnökök segítségével (Dalmy Tibor, Loykó Miklós) számos szerkezet megerősítési munkái mellett, szakértői és tervellenőri munkákra is kiterjedt.

Korábbi egyetemi oktatói munkám itt teljesedett ki a tervezéssel, a kivitelezéssel, úgy érzem igazi szerkezetépítő lettem. Ez azt jelentette, hogy emberi kapcsolataim is megváltoztak, hiszen a munkahelyeken, a tervezőirodákban olyan mérnökök dolgoztak, akiket tanítottam. Nem nagyon tudtam leszoktatni senkit, hogy ne Tanár úrnak szólítsanak, most már beletörődtem, sőt örülök neki.

Az egész, mintegy 30 éve kezdődött tervezői, kivitelezői munkánk természetesen nem csupán a hidakra, hanem épületekre, vagy más mélyépítési szerkezetre is kiterjedt, de természetesen a hidak maradtak meg nekünk fö célpontjaink, hiszen a tervezők (a Dalmy-fivérek, Loykó) hidászok voltak.

A főtervezők munkáját az egyetemről toborzott fiatal kollegák segítették (Balog Ede, Borbás Máté, Böhm Csaba, Csohány András, Györki Gábor, Hodik Zoltán, Kasza Tamás, László Helga, Takács Péter, Molnár Gábor, Pletka Orsika, Woynárovics Tamás) akik ma már vezető beosztásban dolgoznak a szakmában.

\subsection{Hídépítési munkáim a Pannon Freyssinet Kft-nél}

Magyarországon a hidak megerősítéseként alternatív megoldásként ajánlottuk fel a külsőkábeles feszítést, melynek lényege: a kábeleket vagy húzott szerkezetként, például vonórúdként, vagy feszítőmüként alkalmaztuk, ezáltal a szerkezetre ható gravitációs terheket ellentétes eröhatással csökkentettük. A feszítőkábel nagyátmérőjü kemény polietilén gáz-, vagy vízcső, melybe korrózió ellen védett feszítőpászmákat helyeznek el. A korrózióvédelmet a zsírzás és a pászmákra extrudált kemény polietilén biztosítja.

A teherbírás növelésére Zalabaksán erősítettünk meg hidat a Kerka- és a Cupi-patakok felett.

1995-ben a sárvári Rába-híd vasbeton pályaszerkezetét erősítettük meg külsőkábeles feszítéssel (2.ábra).

1997-ben a békéscsabai Szarvasi úti felüljáró hídját erősítettük meg, ennél az erősítésnél az eredetileg szabadszélü lemezhidat a lemezszélekre ráfeszített peremgerendákkal erösítettük.

1999-ben terveztük a 74. sz. fóút Zalaegerszeg elkerülő

2.ábra: A sárvári Rába-híd pályaszerkezetének megerősítése külső kábelekkel

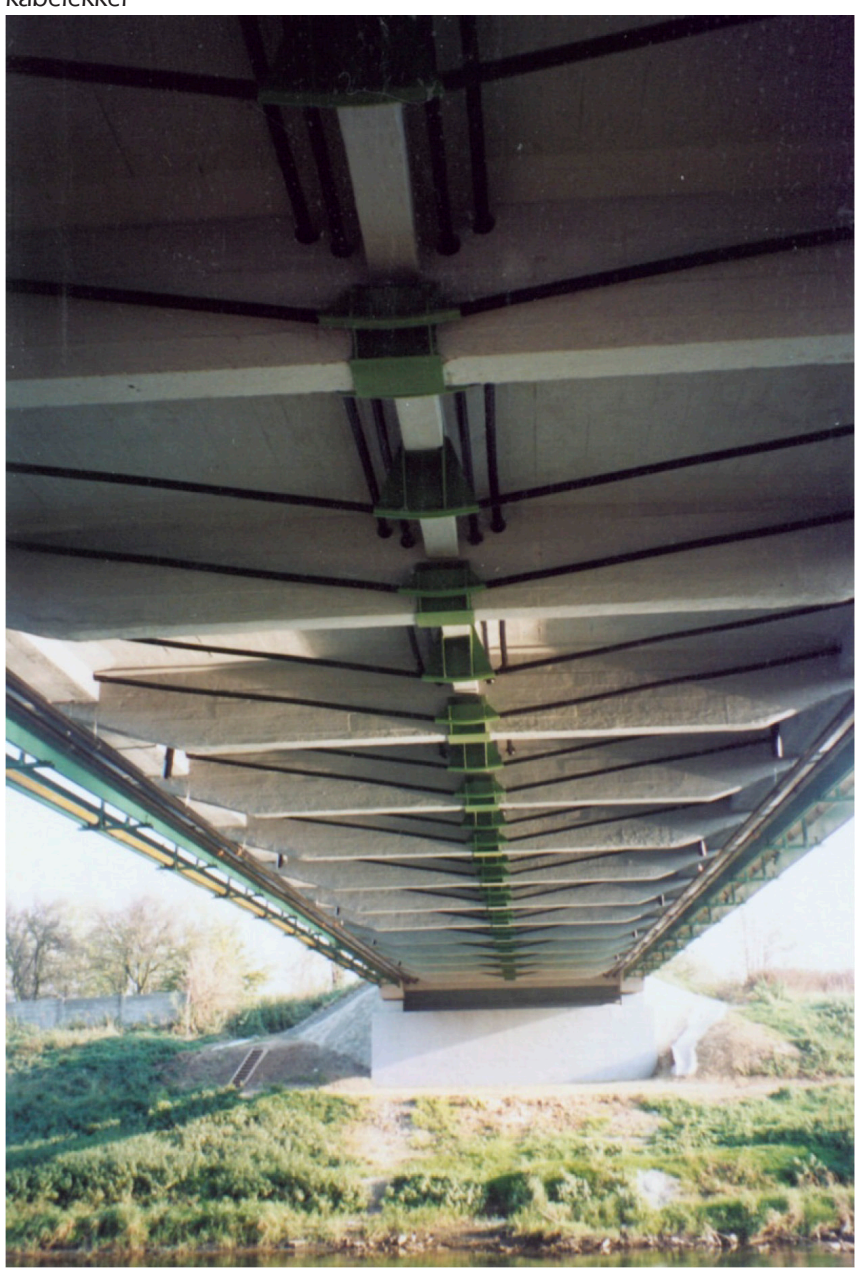




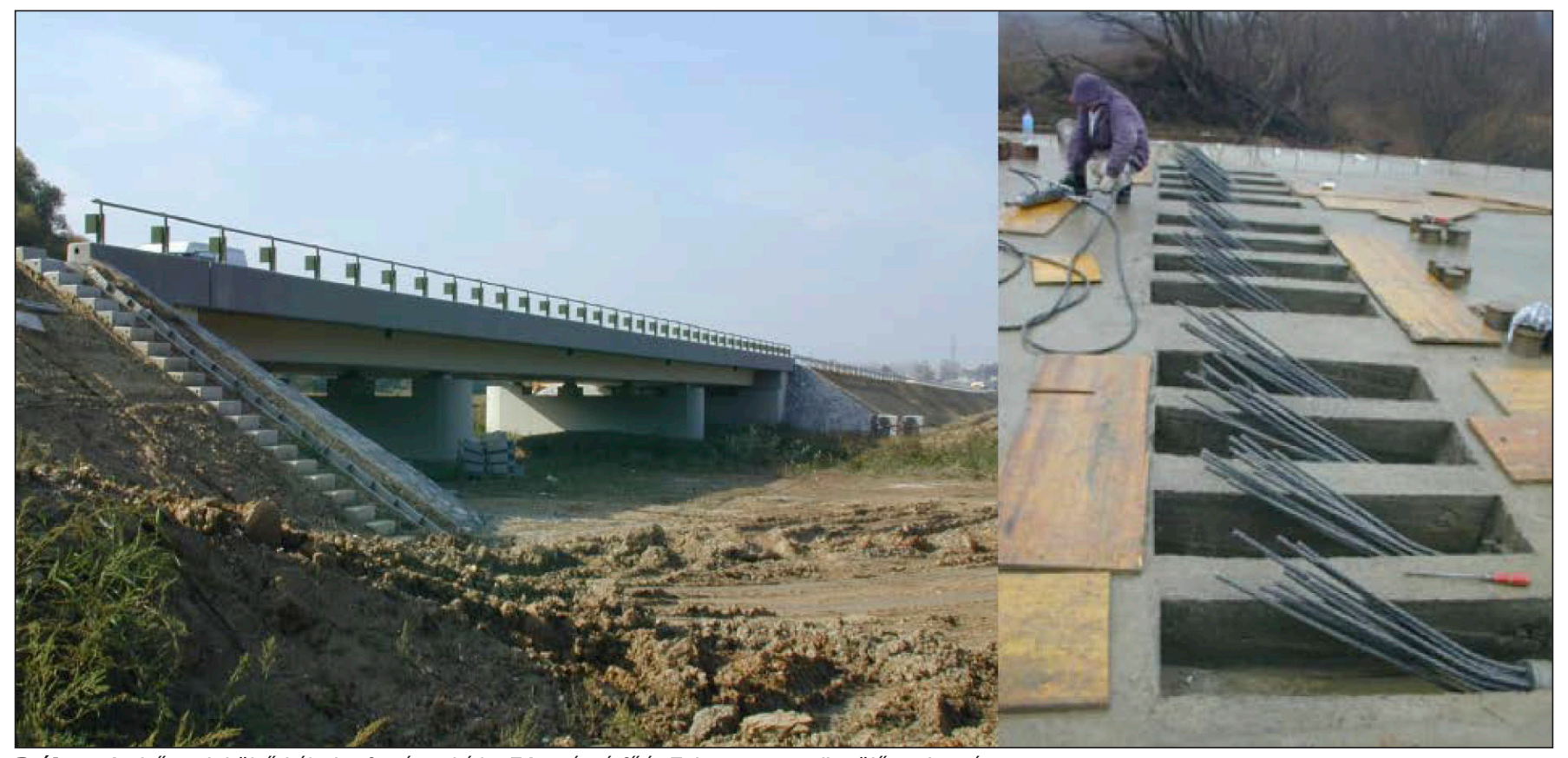

3.ábra: A első csak külső kábeles feszített híd a 74. számú főút Zalaegerszeg elkerülő szakaszán

szakaszán épült Zala-híd feszítését, mely az első, csak külsőkábellel feszített híd Magyarországon (3. ábra).

A külsőkábeles feszítést jól lehet alkalmazni szabadon szerelt, vagy betonozott többtámaszú hidak kiegészítő feszítésére.

Így készítettük el a köröshegyi völgyhíd külsőkábeleinek technológiai terveit és kiviteleztük is 2004-2006 között.

Érdekes munkánk volt az M0 autópálya 2.06-os hídja, melynek lemezszerkezetének átszúródását forgalom alatt öntömörödő betonnal készített oszlopköpenyezéssel és az oszlopfejekre épített szerkezeti gerendákkal akadályoztuk meg.

Híderősítési, hídépítési munkáink megvalósítását az egyetemi munkám során megtanult elméleti alapokra támaszkodva oldottuk meg.

Külön bekezdést igényel a ferdekábeles és az ívhidak függesztőkábeleinek tervezése és szerelése.

2003-2004 között épült a 84.sz. fóút sárvári Rába-hídja. Az ívhíd függesztőkábelekkel épült, a kábelek kialakítása megegyezik az előzőekben ismertetett nagyátmérőjű polietilén csőbe behúzott zsírzott, kemény polietilénnel burkolt pászmákkal.

Az ívek acél szekrény keresztmetszetüek voltak, ezekbe nem lehetett beférni, így egy új lehorgonyzó fejet kellett kitalálni a pászmákhoz, hogy elöre lehessen gyártani és ne ott az ívben kelljen feszíteni.

Erre találtuk ki a Freyssinet Müszaki Osztályának vezetöjével, az azóta is használt lehorgonyzó fejet, melyet HD lehorgonyzó fejnek hívnak, a H Hungary, a D pedig a nevemet jelzi.

A Megyeri híd ferdekábeleinek szerelését a Freyssinet technológiai tervezése szerint 2008-ban építettük, ez volt az első nagynyílású ferdekábeles híd Magyarországon.

A 2006-2007-ben épült Pentele híd függesztőkábeleit is vezetésem alatt építettük.

\subsection{Egyéb tervezési és kiviteli munkák a Pannon Freyssinet Kft-ben}

A Kft. kiemelkedő szellemi kapacitása nagy volumenü tervezési, tervellenőrzési munkák megvalósítását is lehetővé tette.

Kiemelkedik ezek közül az M4 metró tervellenőri munká- ja, továbbá a Margit híd felújítási munkáinak tervellenőrzése. Hasonlóan érdekes volt a debreceni Nagyerdei Stadion körüli szerkezet tervellenőri munkája.

Az utófeszítés tartószerkezeti alkalmazásának magyarországi bevezetését nagyon fontos feladatnak tekintettük.

Mélyépítési mütárgyaknál az utófeszítés anyagtakarékosságot jelent, különösen körszimmetrikus szerkezeteknél, nagyon hatékonyan lehet használni új szerkezetnél, vagy meglévő szerkezetek megerősitésénél.

Ilyen munkáink voltak:

2000-ben a Délpesti Szennyvíztisztító telep iszaprothasztói megerősítésének tervezése és kivitelezése.

2008-ban a budapesti Csepeli Központi Szennyvíztisztító telep iszaprothasztóinak feszítése.

2005-ben a Szegedi Szennyvíztisztító feszítése.

Magasépítési feszítési munkák tervezése és kivitelezése.

A magasépítésben az utófeszítésnek jelentős szerepe lehet, amellyel nem találkoztunk a színrelépésünk elött.

A Freyssinetnél töltött éveim alatti néhány jelentősebb magasépítési utófeszítési munkánk:

- 2009 Pécs Corso feszített alaplemez,

- 2011 SOTE Korányi projekt feszített födémei,

- 2012 Budapest Árkád Üzletközpont feszített szerkezetei.

\subsection{Tervezői és szakértői munkám a Propontis Kft-nél}

A Kft. nevéből is következik (a „hidakért” elnevezés kissé hibásan latinul), hogy a vállalkozást a hidak tervezésére és szakértésére alapítottam 2011-ben. A vállalkozást mély- és magasépítési szerkezetek tervezésére, tervellenőrzésére, szakértésére alapítottam, melyben fontos szerepet szántam a hidak próbaterhelésének.

A tervezési munkáknál nagyon fontos szerepet kapott az utófeszítés. Legjelentősebb utófeszítési tervezési munkáink közül kiemelem:

- a Puskás Stadion tetöszerkezetének lefeszítését,

- a MOL Campus 31 emeletes épülete feszített födémeinek tervezését (4. ábra),

- MOME Campus függesztett födémeit tartó tetöszinti feszített tartórács. 


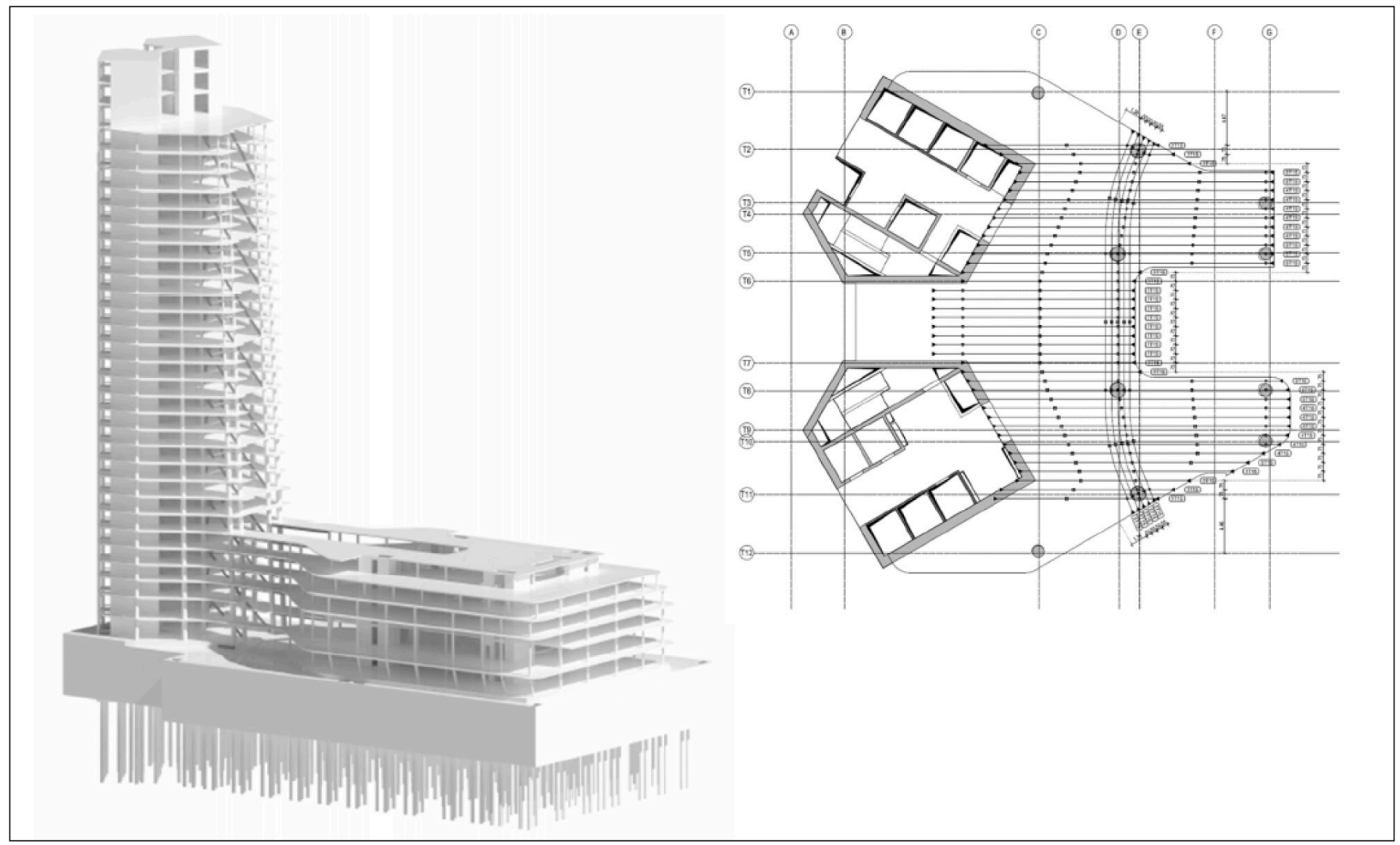

4.ábra: A MOL Campus 31 emeletes épületének feszített födémeinek tervezése

A vállalkozás új gyalogos, közúti és vasúti hidak próbaterhelését végezte, ilyenek például:

- Kaposvári Esterházy gyalogos híd,

- Hansági-föcsatorna fahídja.

Új nagyhíd próbaterhelések közül kiemelem

- Mosoni ferdekábeles Duna-híd mérését,

- M6 autópálya Gyürüs-árok völgyhíd mely több mint 600 m hosszú.

A hidak teherbírásának ellenőrzésére, régi hidak próbaterhelését végeztük, például:

- a budapesti Körvasút feletti Csömöri úti felüljáró híd,

- Szolnok, Kolozsvári vasút feletti híd.

Szakértői vizsgálatok közül kiemelem a

- sárvári Rába-híd vizsgálatát,

- a salgótarjáni 21.úti Tarján-patak tubosider szerkezetét.

\section{MÉRNÖKI KAMARAI MUNKÁM}

Külön kiemelem, szerkezetépítöként végzett munkám egyik legfontosabb állomásaként 2008 és 2016 között Mérnöki Kamara Tartószerkezeti Tagozatának voltam az elnöke.

Erre az időre esik az Eurocode-ok bevezetése, külön kell megemlítenem a szerkezetek kötelező földrengés vizsgálatát. melyet Magyarországnak 2010-ben kötelezően be kellett vezetnie.

A Tartószerkezeti Tagozatban mintegy 3000 statikus tervező van, ebböl hidász 300 fö.

Ekkor vezették be az évi kötelező szakmai továbbképzést, amelyben közre tudtam müködni oly módon is, hogy világhírü hidászokat hívtam meg, például M. Virlogeux, A. Jutila professzort.

Tagozati elnökként vettem részt a Galvani híd nemzetközi tervpályázat bíráló bizottságában elnökhelyetteseként.

Jelenleg a Szakmai Címeket Bíráló Testület elnökeként a vezető tervezői címek odaítélését irányítom.

\section{KITÜNTETÉSEIM}

$\begin{array}{ll}2015 & \text { Menyhárt István-dijj } \\ 2016 & \text { Zielinski Szilárd-díj } \\ 2017 & \text { Az év hidásza } \\ 2020 & \text { Palotás László-díj. }\end{array}$

Ezeket a díjakat szakmai munkám elismeréseként kaptam, mindegyikre büszke vagyok.

Dr. Dalmy Dénes 